\title{
Oil palm and rubber expansion facilitates earthworm invasion in Indonesia
}

\author{
Anton Potapov (1) - Ina Schaefer • Malte Jochum - Rahayu Widyastuti • \\ Nico Eisenhauer $\cdot$ Stefan Scheu
}

Received: 10 March 2020/ Accepted: 16 April 2021/Published online: 29 April 2021

(C) The Author(s) 2021

\begin{abstract}
Deforestation, plantation expansion and other human activities in tropical ecosystems are often associated with biological invasions. These processes have been studied for above-ground organisms, but associated changes below the ground have received little attention. We surveyed rainforest and plantation systems in Jambi province, Sumatra, Indonesia, to investigate effects of land-use change on the diversity and abundance of earthworms - a major group of soilecosystem engineers that often is associated with
\end{abstract}

Supplementary Information The online version contains supplementary material available at https://doi.org/10.1007/ s10530-021-02539-y.

A. Potapov $(\bowtie) \cdot$ I. Schaefer $\cdot$ S. Scheu

J.F. Blumenbach Institute of Zoology and Anthropology, University of Göttingen, Untere Karspüle 2,

37073 Göttingen, Germany

e-mail: potapov.msu@gmail.com

A. Potapov

A.N. Severtsov Institute of Ecology and Evolution, Russian Academy of Sciences, Leninsky prospekt 33, Moscow, Russia 119071

M. Jochum - N. Eisenhauer

German Centre for Integrative Biodiversity Research

(iDiv), Puschstrasse 4, 04103 Leipzig, Germany

M. Jochum · N. Eisenhauer

Institute of Biology, Leipzig University, Puschstrasse 4,

04109 Leipzig, Germany human activities. Density and biomass of earthworms increased 4-30-fold in oil palm and rubber monoculture plantations compared to rainforest. Despite much higher abundance, earthworm communities in plantations were less diverse and dominated by the peregrine morphospecies Pontoscolex corethrurus, often recorded as invasive. Considering the high deforestation rate in Indonesia, invasive earthworms are expected to dominate soil communities across the region in the near future, in lieu of native soil biodiversity. Ecologically-friendly management approaches, increasing structural habitat complexity and plant diversity, may foster beneficial effects of

\author{
R. Widyastuti \\ Department of Soil Sciences and Land Resources, Institut \\ Pertanian Bogor (IPB), Kampus IPB Dramaga, Bogor, \\ Jawa Barat 16680, Indonesia \\ S. Scheu \\ Centre of Biodiversity and Sustainable Land Use, \\ Büsgenweg 1, 37077 Göttingen, Germany
}


invasive earthworms on plant growth while mitigating negative effects on below-ground biodiversity and the functioning of the native soil animal community.

Keywords Land-use change - Sumatra - Biomass . Soil biodiversity $\cdot$ Riparian zone $\cdot$ Seasonal changes . Genetic diversity $\cdot$ COI

\section{Introduction}

Land-use change in the tropics is largely driven by the establishment of high-production agricultural systems in order to provide humanity with food and other agricultural products (Laurance et al. 2014; Edwards et al. 2019). Rainforests are cleared across tropical regions with recent deforestation being especially pronounced in Indonesia (Hansen et al. 2013). Over the last 30 years, most of the lowland rainforests in Sumatra (Indonesia) have been converted into plantations, with oil palm and rubber being the dominating crops (Margono et al. 2012). These land-use changes disturb habitats, degrade biodiversity and provide dispersal vectors for organisms, thereby opening opportunities for invasions by exotic species into the transformed ecosystems (Bellard et al. 2016; Clough et al. 2016; Rembold et al. 2017). Such invasions may have diverse impacts on biodiversity and ecosystem functioning on the local and regional scale, being among the strongest drivers of environmental changes globally (Simberloff 2011; IPBES 2019). For instance, terrestrial invertebrate invaders, on average, reduce plant and animal abundance, and may speed up ecosystem processes such as decomposition (Cameron et al. 2016). In Sumatra, plantations have been reported to be inhabited by a range of alien plant, tramp ant and common bird species (Prabowo et al. 2016; Rembold et al. 2017; J. Drescher personal communication). However, to date, little is known about the potential belowground invasions associated with the recent land-use change in Southeast Asia.

Below-ground invasions are largely unseen and thus have received little attention by science and society. However, below-ground invasions may be as dramatic and drive as large ecosystem changes as those above the ground (Hendrix et al. 2008; Craven et al. 2017). One important example of below-ground invasions is that of earthworms that have very pronounced ecosystem effects through their action as ecosystem engineers (Bohlen et al. 2004; Eisenhauer 2010; Frelich et al. 2019). More than 100 earthworm species are considered to be peregrine, i.e., having a wide distribution range and often being linked to human activities (Hendrix et al. 2008; Blakemore 2009). Human-induced long-distance dispersal likely is the most important mechanism facilitating the invasion of peregrine earthworms into new areas (Hendrix et al. 2008; Cameron and Bayne 2009; Klein et al. 2019). Introduced earthworms may change soil physical and chemical characteristics, nutrient and water cycling, gas emissions and plant communities, thus having a prominent impact on ecosystem functioning (Hale et al. 2006; Eisenhauer et al. 2012; Lubbers et al. 2013; Blouin et al. 2013). Recent metaanalyses summarized effects of introduced earthworms on northern North American forests, showing that earthworm invasions are associated with the decline in diversity and changes in community composition of plants (Craven et al. 2017), reduced soil biodiversity and altered depth distribution of soil communities (Ferlian et al. 2018), as well as homogenization of soil layers substantially changing nutrient pools and fluxes (Ferlian et al. 2020). Increased earthworm density may also cause multitrophic changes that cascade beyond the basal trophic level (Scheu 2003; Wurst 2010), altering the pathways of energy flux through trophic networks and reducing the provisioning of energy to predators (Potapov et al. 2019).

The Indonesian earthworm fauna is largely dominated by Megascolecidae, but also includes a number of species from other earthworm families (e.g., Moniligastridae, Lumbricidae) with 182 species records in total according to DriloBASE (Drilobase Project 2020). More than 50 alien earthworm species were recorded in Southeast Asia, demonstrating a large potential for belowground invasions in the region (Blakemore et al. 2006). Across tropical areas, Pontoscolex corethrurus (Rhinodrilidae) by far is the most frequently recorded peregrine earthworm invader particularly colonizing disturbed but also native ecosystems (Taheri et al. 2018b). It was first described from Brazil, but today has a pantropical distribution with several cryptic lineages (Taheri et al. 2018a; James et al. 2019). Invasion by $P$. corethrurus may result in significant modifications of soil bulk density, biochemical processes and abundance of other soil 
organisms, with the direction of change depending on soil type (Marichal et al. 2010; Taheri et al. 2018b). Most studies on the invasion by $P$. corethrurus were conducted in India, Brazil and Mexico, while only few records exist from Indonesia (Taheri et al. 2018b). Land-use change in tropical rainforest areas was suggested to facilitate the invasion by $P$. corethrurus into soils of high $\mathrm{pH}, \mathrm{C}$ and $\mathrm{N}$ contents in particular after burning (Marichal et al. 2010). Pontoscolex corethrurus and other invasive earthworm species predominantly colonize agricultural fields (Darmawan et al. 2017; Taheri et al. 2018b), but below-ground invasions associated with the expansion of oil palm and rubber plantations across Indonesia (Margono et al. 2014; Vijay et al. 2016) have not been investigated yet.

Biomass of earthworms in oil palm and rubber plantations has been found to exceed that in rainforest in our previous study in Jambi province, Sumatra (Potapov et al. 2019). Building on these findings, here we expanded our sampling to investigate if the abundance of earthworms is systematically higher in plantations in comparison to rainforests. We specifically collected data at (1) riparian sites, (2) different years, (3) soil depths and (4) seasons. Further, we investigated the diversity of earthworm species in rainforest and plantation systems using COI barcoding to reveal if land-use change is associated with the spread of invasive species into lowland landscapes of Sumatra.

\section{Methods}

\section{Study region}

The study was conducted in the framework of the collaborative research project CRC990 "EFForTS" investigating ecological and socioeconomic changes associated with the transformation of lowland rainforest into agricultural systems (https://www.unigoettingen.de/de/310995.html). Four land-use systems, rainforest $(\mathrm{F})$, jungle rubber $(\mathrm{J})$, rubber monoculture $(\mathrm{R})$ and oil palm monoculture $(\mathrm{O})$, were studied in lowlands of Jambi province, Sumatra, Indonesia (average temperature $26.7 \pm 0.2{ }^{\circ} \mathrm{C}$, annual precipitation $2235 \pm 381 \mathrm{~mm}$ ). Sampling plots were established in two landscapes, in and around Harapan rainforest and Bukit Duabelas national park. Each system was replicated eight times (four times in each of the two landscapes) resulting in a total of 32 "core plots". In addition, four replicates of each rainforest, rubber and oil palm monocultures were established in riparian areas in the Harapan landscape (12 "riparian plots"; Fig. 1; Table S1). Rainforest sites were used as control and were close to natural conditions, but underwent selective logging between 1985 and 2000. Jungle rubber sites originated from logged rainforest sites planted with rubber trees (Hevea brasiliensis) and were dominated by rubber with some native tree species interspersed. Rubber and oil palm (Elaeis guineensis) monoculture plantations represent intensive land-use systems with fertilizer addition and regular herbicide application of an age of 10-20 years depending on the sampling event (see below). Most of the studied monocultures represent first-generation plantations and originated from logged and/or burned rainforest or replaced agroforests such as jungle rubber (Margono et al. 2012). Between 1990 and 2013, rainforest cover decreased from 49.5 to $34.5 \%$ in Jambi province, while combined rubber and oil palm cultivation increased from 26.4 to $32.5 \%$ (Grass et al. 2020). Soils at the sampling sites were acrisols with sandy loam texture in the Harapan and clay texture in the Bukit Duabelas landscape (Allen et al. 2016).

\section{Sampling}

In total, five sampling campaigns were conducted for this study (Fig. 1; Table 1). (1) The first sampling campaign took place during October and November 2012 (Barnes et al. 2014). In each of the 32 core plots, three soil samples of $50 \times 50 \mathrm{~cm}$ were excavated to a depth of $20 \mathrm{~cm}$, earthworms were collected manually by hand sorting and stored in $65 \%$ ethanol. In the laboratory, all earthworms were individually measured for length and width and weighed. In total, 848 earthworms were collected and analyzed. (2) The second sampling campaign was conducted during October and November 2013 (Klarner et al. 2017; Potapov et al. 2019). In each of 32 core plots, three soil samples $16 \times 16 \mathrm{~cm}$, litter and the upper $5 \mathrm{~cm}$ of the soil were taken, and earthworms were extracted by heat using a high-gradient extractor, collected in dimethyleneglycol-water solution (1:1) and then stored in $70 \%$ ethanol. All earthworms were individually measured for length and width. In total, 266 


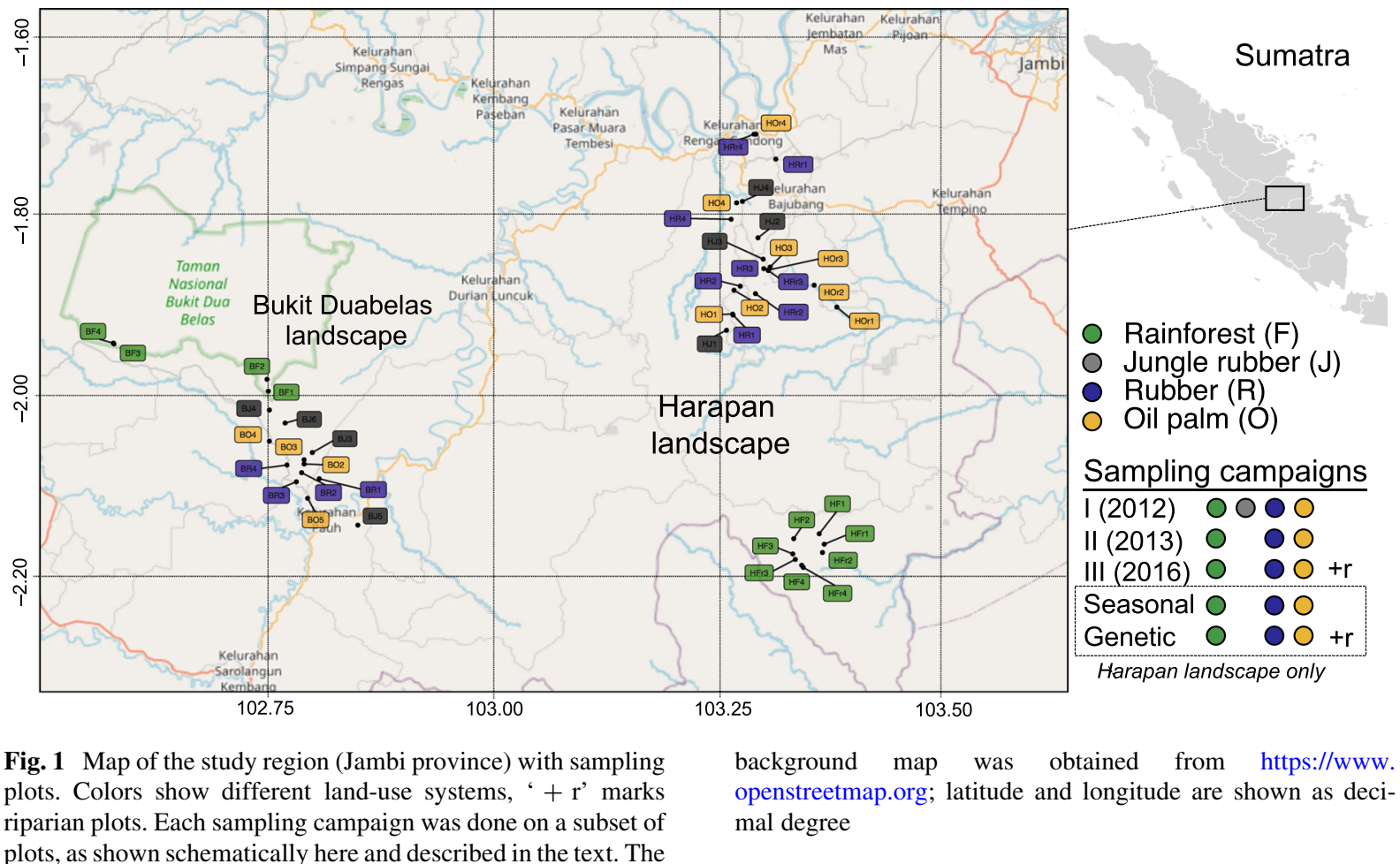

Table 1 Summary of the sampling campaigns conducted

\begin{tabular}{|c|c|c|c|c|}
\hline $\begin{array}{l}\text { Sampling } \\
\text { campaign }\end{array}$ & Sampling dates & Sampling sites & Sampling methods and sample size & Obtained data \\
\hline $\begin{array}{l}\text { I Sampling } \\
\text { campaign }\end{array}$ & $\begin{array}{l}\text { October- } \\
\quad \text { November } 2012\end{array}$ & $\begin{array}{l}32 \text { Core plots across both } \\
\text { landscapes }\end{array}$ & $\begin{array}{l}\text { Hand sorting, } 50 \times 50 \times 20 \text { (width } \times \\
\text { length } \times \text { depth) } \mathrm{cm} \text { soil samples } \\
\text { (three per plot) }\end{array}$ & $\begin{array}{r}\text { Density, body length, } \\
\text { body mass, biomass }\end{array}$ \\
\hline $\begin{array}{l}\text { II Sampling } \\
\text { campaign }\end{array}$ & $\begin{array}{l}\text { October- } \\
\quad \text { November } 2013\end{array}$ & $\begin{array}{l}32 \text { Core plots in both } \\
\text { landscapes }\end{array}$ & $\begin{array}{l}\text { Heat-gradient extraction } \\
16 \times 16 \times 5 \mathrm{~cm} \text { soil samples and } \\
\text { litter (three per plot) }\end{array}$ & $\begin{array}{l}\text { Density, body length, } \\
\text { biomass }\end{array}$ \\
\hline $\begin{array}{l}\text { III Sampling } \\
\text { campaign }\end{array}$ & $\begin{array}{l}\text { October- } \\
\text { November } 2016\end{array}$ & $\begin{array}{l}24 \text { Core plots (no jungle } \\
\text { rubber) in both landscapes } \\
\text { and } 12 \text { riparian plots }\end{array}$ & $\begin{array}{l}\text { Heat-gradient extraction } \\
16 \times 16 \times 5 \mathrm{~cm} \text { soil samples and } \\
\text { litter (three per plot) }\end{array}$ & Density \\
\hline $\begin{array}{l}\text { IV Seasonal } \\
\text { sampling } \\
\text { campaign }\end{array}$ & $\begin{array}{l}\text { March, June, } \\
\text { September and } \\
\text { December } 2017\end{array}$ & $\begin{array}{l}12 \text { Core plots (no jungle } \\
\text { rubber) in Harapan } \\
\text { landscape }\end{array}$ & $\begin{array}{l}\text { Heat-gradient extraction } \\
16 \times 16 \times 5 \mathrm{~cm} \text { soil samples and } \\
\text { litter (one per plot) }\end{array}$ & Density \\
\hline $\begin{array}{l}\text { V Genetic } \\
\text { sampling } \\
\text { campaign }\end{array}$ & October 2017 & $\begin{array}{l}12 \text { Core plots (no jungle } \\
\text { rubber) in Harapan } \\
\text { landscape and } 12 \text { riparian } \\
\text { plots }\end{array}$ & $\begin{array}{l}\text { Tullgren funnels with heating plates } \\
\text { extraction } 16 \times 16 \times 5 \mathrm{~cm} \text { soil } \\
\text { samples and litter (two per plot) }\end{array}$ & $\begin{array}{l}\text { COI sequences, } \\
\text { juvenile proportion } \\
\text { in Pontoscolex spp. }\end{array}$ \\
\hline
\end{tabular}

earthworms were collected. (3) The third sampling campaign was conducted during October and November 2016. All core plots, except for jungle rubber, and all riparian plots were sampled, resulting in a total of
36 plots (three samples per plot). Sampling and extraction were done as in the second sampling campaign. In total, 240 earthworms were collected and used to compare upland (core) and riparian sites. 
Material from these three sampling campaigns was used to assess earthworm abundance in different landuse systems. (4) The fourth sampling campaign ("seasonal") was conducted in 2017. Samples were taken four times a year: end of the wet season (March), middle of the dry season (June), end of the dry season (September), and middle of the wet season (December), on core plots of the Harapan landscape, except for jungle rubber plots. On each of 12 plots in each season, one soil sample of $16 \times 16 \mathrm{~cm}$ comprising litter and the upper $5 \mathrm{~cm}$ of the soil was taken, and earthworms were extracted by heat as described above. In total, 76 earthworms were collected and used for assessing seasonal changes in earthworm abundance (Table S2). (5) The fifth sampling campaign ("genetic") was conducted in October 2017. All core plots of the Harapan landscape except jungle rubber, and all riparian plots were sampled, resulting in a total of 24 plots. On each plot two soil samples of $16 \times 16 \mathrm{~cm}$ comprising litter and the upper $5 \mathrm{~cm}$ of the soil were taken, and earthworms were extracted directly into $96 \%$ ethanol using Tullgren funnels with heating plates (Semenina et al. 2015) and stored in a freezer $\left(-20{ }^{\circ} \mathrm{C}\right)$. In total, 151 earthworms were collected, 104 of which were selected for genetic analysis to assess genetic diversity (see below).

\section{Biomass estimation}

To estimate earthworm biomass, we used data collected during the first sampling campaign to establish region-specific coefficients for a body size-body mass regression. The regression was fitted using $l m$ in $\mathrm{R} \quad 3.5 .3$ ( $\mathrm{R}$ Core Team 2019) as $\ln (-$ mass $) \sim \ln ($ length $)+\log ($ width $)$, where mass is the body mass in gram after storage in ethanol (as proxy for fresh weight), length and width were measured in millimeter and $\ln$ is the natural logarithm. The model had an $\mathrm{R}^{2}$ of 0.853 , an intercept of -7.282 , a length coefficient of 1.075 and a width coefficient of 1.415 (Fig. S1). This equation was used to calculate biomass of earthworms from the second sampling campaign, where only length and width, but not body mass, were measured. Measured body mass from the first campaign and estimated mass from the second sampling campaign were used to analyze the effect of land use on earthworm biomass (Appendix S1).
Genetic analysis

Out of 151 earthworms collected during the "genetic" sampling campaign, we selected 104 individuals. The selection was designed to cover all eight sampling plots in each of the land-use systems and to analyze one to six specimens per plot randomly, depending on availability. We obtained cytochrome c oxidase subunit I (COI) sequences of 72 individuals (69\% success rate), of which 24 individuals were from rainforest, 28 from rubber and 20 from oil palm monoculture (Table S3). For genetic analyses, the final three segments of the hind end of earthworms were cut with a sterile scalpel avoiding transferring soil and gut content from the earthworm. For DNA extraction, we used the Agencourt DNAdvance Kit (Beckman Coulter, Krefeld, Germany) following the manufacturer's protocol. Earthworm tissue was individually transferred into $200 \mu \mathrm{l}$ lysis buffer, without $1 \mathrm{M}$ DTT, on a 96 well plate and $7 \mu \mathrm{l}$ of Proteinase K $(20 \mu \mathrm{g} / \mu \mathrm{l}$, Genaxxon, Ulm, Germany) was added. Samples were incubated overnight on a shaking heat-block at $55{ }^{\circ} \mathrm{C}$ and processed after $18 \mathrm{~h}$ on the automated robot system Biomek 3000 (Beckman Coulter, Krefeld, Germany) using the standard protocol for DNA extraction and an elution volume of $100 \mu \mathrm{l}$. The standard barcoding gene COI was amplified and sequenced. The PCR reaction mix of $25 \mu \mathrm{l}$ volume contained $3 \mu \mathrm{l}$ of template DNA, $12.5 \mu \mathrm{l}$ of SuperHot Mastermix (Genaxxon, Ulm, Germany), $1 \mu \mathrm{l}$ BSA (3\%), $1 \mu \mathrm{l}$ of each primer (10 pM, LCO1490 and HCO2198; Folmer et al. 1994). The PCR started with an initial activation step at $95{ }^{\circ} \mathrm{C}$ for $15 \mathrm{~min}$, followed by 35 amplification cycles (denaturation at $95{ }^{\circ} \mathrm{C}$ for $30 \mathrm{~s}$, annealing at $53{ }^{\circ} \mathrm{C}$ for $60 \mathrm{~s}$, elongation at $72{ }^{\circ} \mathrm{C}$ for $60 \mathrm{~s}$ ), and a final elongation step at $72{ }^{\circ} \mathrm{C}$ for $10 \mathrm{~min}$, and products were sequenced at SeqLab Göttingen (Microsynth). Sequences were checked with Geneious Prime 2019 (www.geneious.com) and ambiguous positions were corrected using the electropherograms. Consensus sequences were aligned in AliView v1.25 (Larsson 2014) using default settings and truncated to equal lengths. The resulting alignment was analyzed for haplotype diversity using the DNA-to-haplotype collapser and converter of the online tool FaBox 1.5 (Villesen 2007). Haplotype identities were checked using the nucleotide BLAST algorithm of the NCBI database (www.ncbi.nlm.nih. gov; Table S3). We further manually compared 
sequences of $P$. corethrurus with those available in NCBI to identify the particular lineage of this morphospecies (i.e., cryptic species) (Taheri et al. 2018a). To verify molecular identification, we additionally distinguished morphotypes of Pontoscolex spp. (Taheri et al. 2018a; Fig. S2) and estimated the proportion of juvenile earthworms in the material of the genetic sampling campaign (Table S5).

Data analysis

Statistical analyses were done in $\mathrm{R}$ 3.5.3 with $\mathrm{R}$ studio interface 1.0.143 (RStudio, Inc.). For the analyses, samples within plots were pooled and plots were treated as replicates. The effect of land use $(F, J, R, O)$ on the number of earthworms per plot was evaluated using generalized linear models with negative binomial distribution using glm.nb in the MASS package. Data over dispersion was tested with the AER package. Two models were run separately: the first model was based on the data from the first sampling campaign (2012, sampling 0-20 cm of soil) and included land use and region (Harapan vs. Bukit duabelas) and their interaction as factors; the second model was based on the data from the second and third sampling campaigns (2013 and 2016, sampling 0-5 cm of soil) and included land use, region, their interaction and sampling year as factors. Pairwise differences among landuse systems in the models for abundance were tested using the glht package in the multcomp package. The data on biomass was very heterogeneous and was not well described by Gaussian, log-normal or gamma generalized linear models; thus, we fitted linear models using generalized least squares using $g l s$ in the nlme package. These models allowed us to explicitly account for unequal variances in different land-use systems by setting varIdentform $=\sim 1 \mid$ Landuse $)$. Pairwise differences among land-use systems in the models for biomass were tested using non-parametric Median.test in the agricolae package. To test for differences in earthworm abundance between upland and riparian areas, we used data from the third sampling campaign and applied glm.nb with riparian status (true or false), land use and their interaction as factors. To inspect for differences in seasonal changes in earthworm abundance among land-use systems, we used data from the "seasonal" sampling and applied glm.nb with month (March, June, September and December), land use and their interaction as factors. To estimate earthworm diversity in each land-use system, we extrapolated the number of haplotypes using specpool based on individuals (Chao estimator) and also displayed rarefaction curves using specaccum in the vegan package in R. Proportion of Pontoscolex spp. in different land-use systems was illustrated using the bipartite package. Data in the text are presented as means and $1 \mathrm{SD}$.

\section{Results}

In the top $20 \mathrm{~cm}$ of soil (sampling in 2012), the number of earthworms in jungle rubber and both rubber and oil palm monoculture plantations was 15-30 times higher (Fig. 2a; effect of land-use system: $\left.\chi_{3}^{2}=89.8, p<0.0001\right)$ and biomass was about 10 times higher (effect of land-use system: $\chi_{3}^{2}=26.4$, $p<0.0001)$ compared to rainforest. Among the agricultural systems, rubber monoculture had
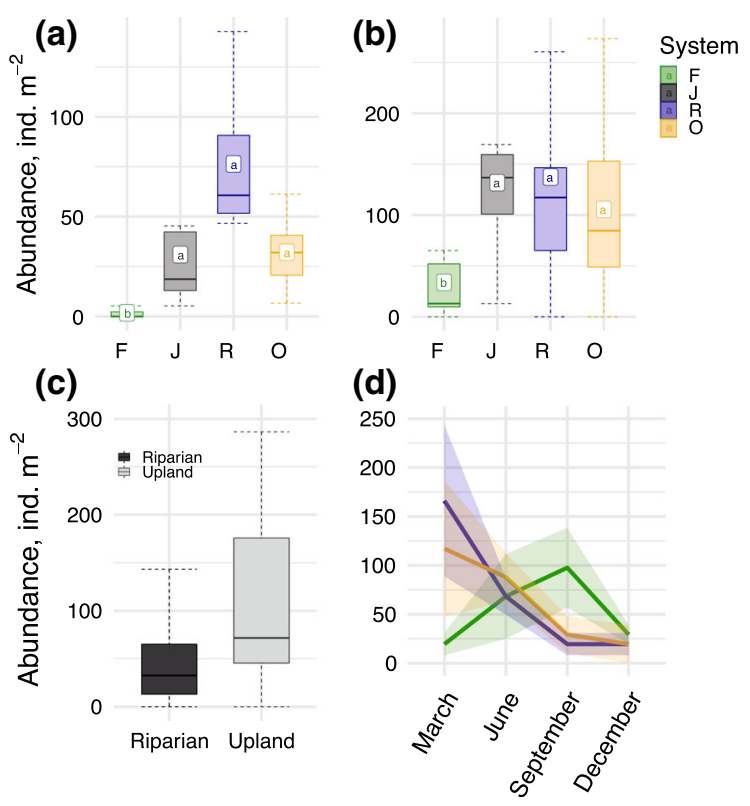

Fig. 2 Abundance of earthworms in different land-use systems. Comparison of land-use systems based on sampling to the depth of $20 \mathrm{~cm}$ (a, first sampling campaign) and to the depth of $5 \mathrm{~cm}$ (b, second and third sampling campaigns); upland versus riparian sites (c, third sampling campaign); seasonal variation in different land-use systems (d, seasonal sampling campaign). Rainforest (F, green), jungle rubber (J, grey), rubber monoculture $(\mathrm{R}$, blue), oil palm monoculture $(\mathrm{O}$, yellow). White labels on the panels $a$ and $b$ represent mean values, means sharing the same letter are not significantly different (Tukey contrasts). For seasonal changes, ribbons represent standard errors of means 
significantly higher biomass of earthworms (fresh mass 15.8 $\mathrm{SD} 12.6 \mathrm{~g} \mathrm{~m}^{-2}$ ) than jungle rubber (4.6 SD $4.5 \mathrm{~g} \mathrm{~m}^{-2}$ ) and oil palm monoculture (5.6 SD $3.9 \mathrm{~g} \mathrm{~m}^{-2}$ ). In rainforest biomass averaged only 0.5 SD $1.0 \mathrm{~g} \mathrm{~m}^{-2}$. In the litter and top $5 \mathrm{~cm}$ of soil (second and third sampling campaigns in 2013 and 2016), the number of earthworms was about four times higher (effect of land-use system: $\chi_{3}^{2}=32.9$, $p<0.0001$ ), while the biomass in all agricultural systems was about 20 times higher (reaching the maximum 16.2 $\mathrm{SD} 14.7 \mathrm{~g} \mathrm{~m}^{-2}$ in jungle rubber) compared to rainforest $\left(0.6 \mathrm{SD} 0.9 \mathrm{~g} \mathrm{~m}^{-2}\right.$; effect of land-use system: $\chi_{3}^{2}=41.5, p<0.0001$; Fig. $2 b$ ). The discrepancy in the decline in biomass and abundance between the two methods was due to the underrepresentation of small earthworm individuals by hand sorting especially in rainforest (Fig. S2).

The number of earthworms averaged 134.5 SD 160.1 ind. $\mathrm{m}^{-2}$ in upland but only 44.5 SD 43.9 in riparian sites (effect of riparian area: $\chi^{2}{ }_{1}=11.2$, $p=0.0008$; Fig. 2c). In the 'seasonal' sampling campaign earthworm abundance was lowest in December (22.8 SD 26.1 ind. $\mathrm{m}^{-2}$ ) and highest in March (100.91 SD 126.5 ind. $\mathrm{m}^{-2}$; effect of season: $\left.\chi_{1}^{2}=12.9, p=0.0048\right)$. However, seasonal changes were asynchronous in different land-use systems with the number of earthworms being high in plantations and low in rainforest in March, and the opposite being true in September (season $\times$ land use interaction: $\chi_{1}^{2}=15.1, \quad p=0.0197$; Fig. $2 d$ ). More detailed results of statistical models are given in Appendix S1.

The genetically analyzed samples showed that haplotype richness was considerably higher in rainforest (Chao-rarefied haplotype richness 65.0 SD 42.2) than in rubber (14.7 SD 11.3) and oil palm monoculture plantations (14.6 SD 11.1; Fig. 3). Overall, 50 out of 72 individuals were assigned to the morphospecies $P$. corethrurus, which represented $>50 \%$ of the individuals in oil palm monoculture and was the only morphospecies recorded in rubber monoculture plantations. Pontoscolex corethrurus was also present in rainforest, but at low abundance sharing dominance with other taxa (Fig. 3). In total, ten haplotypes were found within the morphospecies of $P$. corethrurus, five in rainforest, seven in rubber and four in oil palm monoculture plantations. The two most abundant haplotypes were present in all three land-use systems, while haplotypes specific for certain land-use systems were only represented by single individuals (Tables S3 and S4). Although comprising different haplotypes, all sequences of $P$. corethrurus matched Lineage 1 of $P$. corethrurus, i.e. $P$. corethrurus sensu stricto. The other sequences of earthworms poorly matched records of Megascolecidae and in part also Lumbricidae (80-85\% similarity in most of the cases). Morphological identification of Pontoscolex spp. matched the genetic identification. The proportion of juvenile individuals among the earthworms that were morphologically identified as Pontoscolex spp. averaged $67 \pm 45 \%$ in rainforest, $82 \pm 19 \%$ in rubber, and $84 \pm 20 \%$ in oil palm (Table S5). For accession numbers of COI sequences of the ten haplotypes of $P$. corethrurus see Table S6 (MT975675-MT975684). All other earthworm sequences were not submitted to a public database due to missing morphological identification, but are available from the corresponding author on request.

\section{Discussion}

Here we provided the first detailed assessment of how conversion of tropical lowland rainforest into oil palm and rubber plantations, the dominant agricultural systems in Sumatra and other regions in Southeast Asia (Margono et al. 2014; Corley and Tinker 2016; Grass et al. 2020), changes earthworm communities and facilitates belowground invasions. Our results are straightforward: the density and biomass of earthworms in plantation systems exceeded that in rainforest by factors of 4-30. The differences in earthworm density between land-use systems varied with season and were also prominent, although less pronounced, in riparian sites. Despite much higher abundance, earthworm communities in plantations were much less diverse with monoculture communities having far lower numbers of haplotypes and being dominated by the peregrine morphospecies $P$. corethrurus known as invasive species across tropical regions (Brown et al. 2006; Taheri et al. 2018b).

Context of the earthworm invasion

Here and below, we use the term 'invasive' following Valéry et al. (2008) “....species' acquiring a competitive advantage following the disappearance of natural obstacles to its proliferation, which allows it to spread rapidly and to conquer novel areas within 
(a)

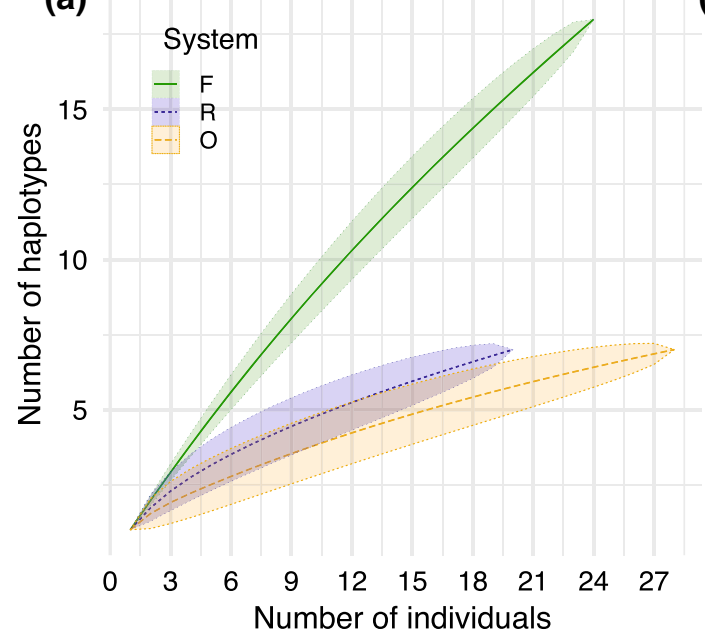

Fig. 3 Genetic diversity of earthworm communities in different land-use systems. Rainforest (green, F), rubber monoculture (R, blue), oil palm monoculture (O, yellow). Rarefaction curves for the number of haplotypes based on individuals, semi-transparent ribbons reflect standard deviations (a). Connection width in the

recipient ecosystems in which it becomes a dominant population". Pontoscolex corethrurus, specifically Lineage 1, has a pantropical distribution and among other countries was recorded from Brazil, where the species was first described, and from Malysia (Taheri et al. 2018a; James et al. 2019). The suggested origin of the family Rhinodrilidae is South America (Righi 1984; Anderson et al. 2017), which fits well to the South American origin of the rubber tree H. brasiliensis, the crop that benefited $P$. corethrurus most in our study. Oil palm, the dominant crop in the region, originates from Africa, but today is planted across tropical lowlands (Corley and Tinker 2016). Although the history of the expansion of $P$. corethrurus remains unclear, human-induced occasional dispersal with soil and plants likely facilitated its spread (Taheri et al. 2018b). Considering the long cultivation history of rubber and oil palm in Indonesia, going back to the early twentieth century, and the recent massive expansion of these crops on Sumatra after the 1970s and 1990s (Barlow 1997; Margono et al. 2012; Corley and Tinker 2016), different earthworm invasion scenarios are possible. The most abundant haplotype of $P$. corethrurus in plantations was also found in rainforest, together with four other haplotypes. Whether the morphospecies was introduced with recent intensive deforestation or populations proliferated earlier after

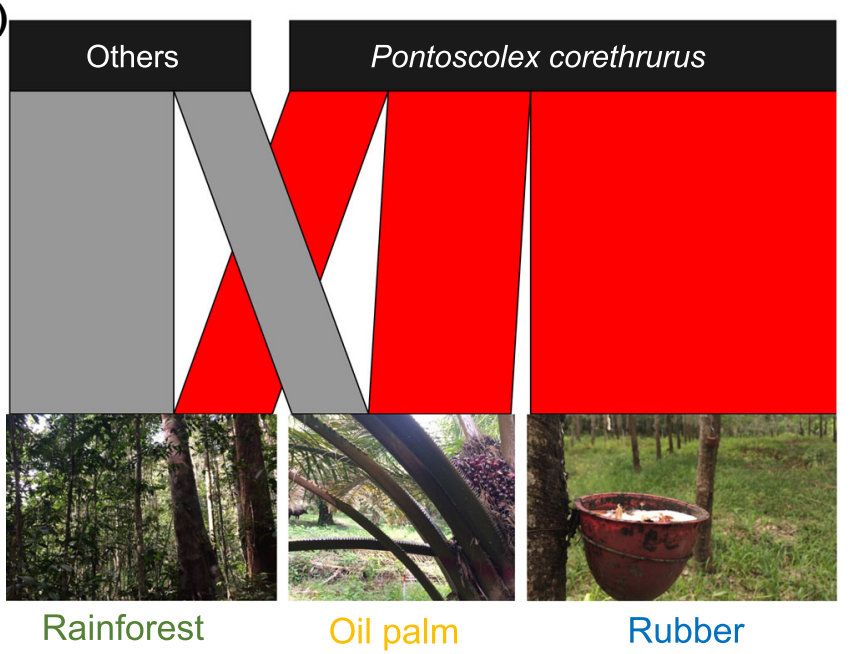

bipartite network (b) shows the relative abundance of Pontoscolex corethrurus in each land-use system among the total of 72 sequenced individuals (data is based only on the 'genetic' sampling campaign)

landscape transformation remains unclear, calling for studies at larger regional scale (Klein et al. 2019). The matches of sequences of other earthworm species in our dataset were poor and usually only at family level (80 to $85 \%$ match in the NCBI; Table S3) suggesting that they represent species not yet sequenced. Further, PCRs were negative or sequences were of low quality for about $30 \%$ of the individuals studied, indicating that we likely underestimated earthworm diversity and that comprehensive taxonomic work including sequencing needs to be done in the region. Below we discuss potential reasons and consequences of the invasion, finishing with potential strategies to control it.

\section{Factors favoring earthworm invasion}

Factors favoring the expansion of peregrine earthworms in the tropics are well studied. Our results match earlier findings that in particular $P$. corethrurus often proliferates in converted habitats, such as croplands, pastures, urban areas and gardens (Marichal et al. 2010), but may also colonize forests (Taheri et al. 2018b). A study from Java (Indonesia) showed a decline in native forest earthworm species in coffee and fruit vegetable plantations, while the exotic Ocnerodrilus occidentalis (Ocnerodrilidae) and $P$. 
corethrurus became dominant (Darmawan et al. 2017). Another study from Malaysia showed that oil palm plantations were only colonized by $P$. corethrurus (Sabrina et al. 2009). Pontoscolex corethrurus is known to colonize soils of high $\mathrm{pH}, \mathrm{N}$ and $\mathrm{P}$ availability (Marichal et al. 2010; Taheri et al. 2018b). Matching these findings, at our study sites, $P$ availability and $\mathrm{pH}$ are higher in plantation systems than in rainforest (Allen et al. 2016). Pontoscolex corethrurus was also observed to be abundant in habitats with scarce litter resources (Marichal et al. 2010; Shilenkova and Tiunov 2015), and this also matches our study sites, where the litter layer is less pronounced in plantation systems, in particular in oil palm, than in rainforest (Krashevska et al. 2015). Changes in environmental conditions associated with deforestation were shown to negatively impact foremost native earthworms species and this may open up niches for $P$. corethrurus thereby facilitating its proliferation (Marichal et al. 2010). The success of $P$. corethrurus in colonizing disturbed habitats may be facilitated by parthenogenetic reproduction, high fecundity, short development time, and reproductive and environmental plasticity (Taheri et al. 2018b).

Pontoscolex corethrurus is an endogeic geophagous earthworm species that was suggested to derive much of its tissue carbon from the rhizosphere in sugarcane plantations (Spain et al. 1990). Findings of our study suggest that this may not uniformly apply. Rubber is harvested by cutting the tree phloem, which reduces the allocation of carbon compounds to roots and, correspondingly, is likely reducing rhizodeposition. Despite that, P. corethrurus was particularly abundant in rubber monoculture plantations and was the only morphospecies recorded there, based on our 'genetic' sampling campaign in 2017. This may point to high trophic flexibility of $P$. corethrurus, allowing it to colonize habitats differing in resource availability. In addition, the density of large invertebrate predators in oil palm and rubber plantations is much lower than in rainforest (Barnes et al. 2014; Potapov et al. 2019), which may also facilitate $P$. corethrurus to thrive without much natural enemies.

Interestingly, the density of earthworms in the top $5 \mathrm{~cm}$ of soil declined during the dry season in plantations but not in rainforest suggesting that earthworms in plantations are more susceptible to reduced summer precipitation (Drescher et al. 2016) and either die or move to deeper soil layers.
Potentially, this reflects that $P$. corethrurus dominating in plantations is more sensitive to soil desiccation than native species dominating in rainforest, but this needs further investigation.

\section{Consequences of earthworm invasion}

Consequences of the invasion by $P$. corethrurus for ecosystem processes also have been intensively studied. Pontoscolex corethrurus is generally known to compact soil and enhance $\mathrm{N}$ and $\mathrm{P}$ availability (Lavelle and Martin 1992; Lopez-Hernandez et al. 1993; Sabrina et al. 2009; Taheri et al. 2018b). Earthworms in general are known to accelerate organic matter and nutrient turnover, usually having positive effects on plant growth in the tropics (Brown et al. 1999). However, the magnitude and direction of the effects vary with soil characteristics and land use (Taheri et al. 2018b). Potential negative effects include the decline in herbaceous vegetation and tree seedlings resulting e.g., in shifts in plant-community composition in natural forests (Hale et al. 2006; Craven et al. 2017), the increase in net soil greenhouse-gas emissions (Lubbers et al. 2013), and reduced soil biodiversity (Ferlian et al. 2018).

Earthworm expansions are negatively affecting soil biodiversity on multiple trophic levels. The density of $P$. corethrurus is often inversely correlated with the density of other earthworm species, especially native ones (Lapied and Lavelle 2003; Taheri et al. 2018b). The dominance of the endogeic $P$. corethrurus and the exclusion of other functional groups of earthworms (epigeic and anecic) is expected to negatively affect ecosystem multifunctionality that depends on intact earthworm communities (Eisenhauer et al. 2012). However, changes in the composition of earthworm communities may also be due to changes in environmental conditions associated with deforestation rather than being caused by interactions between earthworm species (Marichal et al. 2010). Earthworms are known to impact nematodes and microorganisms (Lafont et al. 2007; Blouin et al. 2013), with evident negative effects on meso- and macrofauna (Eisenhauer 2010; Ferlian et al. 2018). Earthworms may function as 'trophic whales' in soil food webs, sequestering a large proportion of energy and reducing its propagation to higher trophic levels (Schwarzmüller et al. 2015; Potapov et al. 2019). 
Overall, the invasion of earthworms is likely to accelerate nutrient cycling and to improve plant growth, but in the long-term may also contribute to depleting nutrient and carbon stocks in soil (Ferlian et al. 2020). Further, it may detrimentally affect biodiversity of understory plants and soil arthropods, thereby simplifying food-web structure and reducing ecosystem multifunctionality (Eisenhauer et al. 2019).

\section{The future of earthworm invasion}

The high abundance of earthworms in rubber and oil palm plantations connects our findings from Jambi province to changing land use at regional scales. Deforestation in Sumatra, Kalimantan, and other territories in Indonesia and Malaysia increased during the last 20-30 years, resulting in a large fraction of the lowland rainforest in the region being converted into plantations (Margono et al. 2014). Indonesia today produces more palm oil than any other country in the world and is overtaking deforestation rates in Brazil (Margono et al. 2014; Vijay et al. 2016). Our study was conducted approximately 30 years after massive landuse changes in Sumatra, suggesting that this period allows for drastic changes in earthworm communities to happen across the landscape. Our results suggest that the expansion of oil palm plantations will be followed by earthworm invasions and the spread of exotic generalists on large spatial scales. Whether this will result in mitigating or exaggerating effects of the conversion of rainforest into plantation systems on ecosystem services remains unclear, but is important to be investigated and potentially to be controlled. Notably, earthworms were less abundant in riparian areas, suggesting that these areas are more resistant to invasions by peregrine earthworms underlining their conservation potential.

Overall, the study documents that the conversion of rainforest into plantation systems facilitates the invasion by peregrine earthworms, with rubber monoculture plantations being most intensively colonized by $P$. corethrurus, potentially due to common evolutionary history of rubber trees and rhinodrilid earthworms. Facilitation of earthworm invasions in intensively managed monoculture plantations is likely to beneficially affect plant growth, but may reduce the diversity of other soil animals and the services they provide (Barnes et al. 2014; Clough et al. 2016; Potapov et al. 2019). Such negative effects may be mitigated by increasing habitat structure complexity, e.g. by increasing the amount of litter and coverage by understory vegetation (Ashton-Butt et al. 2018; Potapov et al. 2020). Recent research has shown that even moderate changes in existing practices of fertilization and weeding may beneficially affect biodiversity and ecosystem processes without reducing economic profit (Darras et al. 2019; Grass et al. 2020). Such ecologically-friendly approaches are promising and may allow to take advantage of positive effects of increased earthworm abundance on plant growth, while mitigating negative effects on biodiversity.

Acknowledgements This study was funded by the Deutsche Forschungsgemeinschaft (DFG, German Research Foundation)-Project ID 192626868 - SFB 990 in the framework of the collaborative German-Indonesian research project CRC990/EFForTS. We thank the following persons and organizations for granting us access to and use of their properties: local plot owners, PT REKI and Bukit Duabelas National Park. Sampling of animals used in this study was based on Collection Permits No. 2695/IPH.1/KS.02/XI/2012, S.07/ KKH-2/2013, and 2841/IPH.1/KS.02.04/X/2016, issued by the Indonesian Ministry of Forestry (PHKA). The authors are grateful to A. Barnes, S. Mumme, Megawati, A. Nur Faidah, B. Klarner and M. Italiensia who contributed to the physically and physiologically challenging field sampling campaigns, as well as measuring and counting of earthworms. We also thank U. Brose for designinng and supervision of the first sampling campaign. M. Jochum and N. Eisenhauer acknowledge support from the European Research Council (ERC) under the European Union's Horizon 2020 research and innovation program (grant agreement no. 677232 to NE) and the German Centre for Integrative Biodiversity Research Halle-Jena-Leipzig, funded by the German Research Foundation (FZT 118).

Authors' contributions AP, SS, NE and MJ designed the study. AP, MJ and RW were involved in field sampling and export. IS did molecular work and sequence data evaluation. AP did morphological sorting statistical analysis and prepared the first draft of the paper. All authors read and approved the final manuscript.

Funding Open Access funding enabled and organized by Projekt DEAL. The study was supported by the following bodies and grants: DFG-SFB 990 and FZT 118; ERC-677232.

Availability of data and material Raw data supporting the study conclusions are provided in the Supplementary materials and available from Figshare, https://doi.org/10.6084/m9. figshare.14369786.

Code availability $\mathrm{R}$ commands and packages used for the statistical analysis are described in detail in the methods section. Statistical model formulas are given in the Supplementary materials. 


\section{Declarations}

Conflict of interest The authors declare that they have no conflict of interest.

Open Access This article is licensed under a Creative Commons Attribution 4.0 International License, which permits use, sharing, adaptation, distribution and reproduction in any medium or format, as long as you give appropriate credit to the original author(s) and the source, provide a link to the Creative Commons licence, and indicate if changes were made. The images or other third party material in this article are included in the article's Creative Commons licence, unless indicated otherwise in a credit line to the material. If material is not included in the article's Creative Commons licence and your intended use is not permitted by statutory regulation or exceeds the permitted use, you will need to obtain permission directly from the copyright holder. To view a copy of this licence, visit http://creativecommons.org/licenses/by/4.0/.

\section{References}

Allen K, Corre MD, Kurniawan S et al (2016) Spatial variability surpasses land-use change effects on soil biochemical properties of converted lowland landscapes in Sumatra, Indonesia. Geoderma 284:42-50. https://doi.org/10.1016/j. geoderma.2016.08.010

Anderson FE, Williams BW, Horn KM et al (2017) Phylogenomic analyses of Crassiclitellata support major Northern and Southern hemisphere clades and a Pangaean origin for earthworms. BMC EvolBiol 17:123. https://doi.org/10. 1186/s12862-017-0973-4

Ashton-Butt A, Aryawan AAK, Hood ASC et al (2018) Understory vegetation in oil palm plantations benefits soil biodiversity and decomposition rates. Front For Glob Change 1:10. https://doi.org/10.3389/ffgc.2018.00010

Barlow C (1997) Growth, structural change and plantation tree crops: the case of rubber. World Dev 25:1589-1607. https://doi.org/10.1016/S0305-750X(97)00059-4

Barnes AD, Jochum M, Mumme S et al (2014) Consequences of tropical land use for multitrophic biodiversity and ecosystem functioning. Nat Commun 5:5351. https://doi. org/10.1038/ncomms6351

Bellard C, Genovesi P, Jeschke JM (2016) Global patterns in threats to vertebrates by biological invasions. Proc R Soc B 283:20152454. https://doi.org/10.1098/rspb.2015.2454

Blakemore RJ (2009) Cosmopolitan earthworms - a global and historical perspective. In: Shain DH (ed) Annelids in modern biology. John Wiley, Hoboken, pp 257-283

Blakemore RJ, Ito MT, Kaneko N (2006) Alien earthworms in the Asia/Pacific region with a checklist of species and the first records of Eukerria saltensis (Oligochaeta: Ocnerodrilidae) and Eiseniella tetraedra (Lumbricidae) from Japan, and Pontoscolex corethrurus (Glossoscolecidae) from Okinawa. In: Assessment and Control of Biological Invasion Risks. IUCN, Gland, Switzerland and Cambridge,
UK, and Shoukadoh Book Sellers, Kyoto, Japan, pp 173-181

Blouin M, Hodson ME, Delgado EA et al (2013) A review of earthworm impact on soil function and ecosystem services: earthworm impact on ecosystem services. Eur J Soil Sci 64:161-182. https://doi.org/10.1111/ejss. 12025

Bohlen PJ, Scheu S, Hale CM et al (2004) Non-native invasive earthworms as agents of change in northern temperate forests. Front Ecol Environ 2:427-435. https://doi.org/10. 1890/1540-9295(2004)002[0427:NIEAAO]2.0.CO;2

Brown GG, Pashanasi B, Villenave C et al (1999) Effects of earthworms on plant production in the tropics. In: Lavelle P, Brussaard L, Hendrix PF (eds) Earthworm management in tropical agroecosystems. CABI Publishing, Wallingford, pp 87-147

Brown GG, James SW, Pasini A et al (2006) Exotic, peregrine, and invasive earthworms in Brazil: diversity, distribution, and effects on soils and plants. Carib J Sci 42:339-358

Cameron EK, Bayne EM (2009) Road age and its importance in earthworm invasion of northern boreal forests. J ApplEcol 46:28-36. https://doi.org/10.1111/j.1365-2664.2008. 01535.x

Cameron EK, Vilà M, Cabeza M (2016) Global meta-analysis of the impacts of terrestrial invertebrate invaders on species, communities and ecosystems: ecological impacts of terrestrial invertebrate invaders. Glob EcolBiogeogr 25:596-606. https://doi.org/10.1111/geb.12436

Clough Y, Krishna VV, Corre MD et al (2016) Land-use choices follow profitability at the expense of ecological functions in Indonesian smallholder landscapes. Nat Commun 7:13137. https://doi.org/10.1038/ncomms13137

Corley RHV, Tinker PB (2016) The oil palm, 5th edn. WileyBlackwell, Chichester

Craven D, Thakur MP, Cameron EK et al (2017) The unseen invaders: introduced earthworms as drivers of change in plant communities in North American forests (a metaanalysis). Glob Change Biol 23:1065-1074. https://doi. org/10.1111/gcb.13446

Darmawan A, Atmowidi T, Manalu W, Suryobroto B (2017) Land-use change on Mount Gede, Indonesia, reduced native earthworm populations and diversity. Aust J Zool 65:217. https://doi.org/10.1071/ZO17028

Darras K, Corre MD, Formaglio G et al (2019) Reducing fertilizer and avoiding herbicides in oil palm plantationsecological and economic valuations. Front For Glob Change 2:65. https://doi.org/10.3389/ffgc.2019.00065

Drescher J, Rembold K, Allen K et al (2016) Ecological and socio-economic functions across tropical land use systems after rainforest conversion. Philos Trans R Soc B: BiolSci 371:20150275. https://doi.org/10.1098/rstb.2015.0275

Drilobase Project (2020) DriloBASE: World Earthworm Database. http://taxo.drilobase.org. Accessed 4 Sep 2020

Edwards DP, Socolar JB, Mills SC et al (2019) Conservation of tropical forests in the anthropocene. CurrBiol 29:R1008R1020. https://doi.org/10.1016/j.cub.2019.08.026

Eisenhauer N (2010) The action of an animal ecosystem engineer: identification of the main mechanisms of earthworm impacts on soil microarthropods. Pedobiologia 53:343-352. https://doi.org/10.1016/j.pedobi.2010.04.003

Eisenhauer N, Fisichelli NA, Frelich LE, Reich PB (2012) Interactive effects of global warming and 'global worming' 
on the initial establishment of native and exotic herbaceous plant species. Oikos 121:1121-1133. https://doi.org/10. 1111/j.1600-0706.2011.19807.x

Eisenhauer N, Ferlian O, Craven D et al (2019) Ecosystem responses to exotic earthworm invasion in northern North American forests. RIO 5:e34564. https://doi.org/10.3897/ rio.5.e34564

Ferlian O, Eisenhauer N, Aguirrebengoa M et al (2018) Invasive earthworms erode soil biodiversity: a meta-analysis. J AnimEcol 87:162-172. https://doi.org/10.1111/1365-2656. 12746

Ferlian O, Thakur MP, Castañeda González A et al (2020) Soil chemistry turned upside down: a meta-analysis of invasive earthworm effects on soil chemical properties. Ecology. https://doi.org/10.1002/ecy.2936

Folmer O, Black M, Hoeh W et al (1994) DNA primers for amplification of mitochondrial cytochrome $\mathrm{c}$ oxidase subunit I from diverse metazoan invertebrates. Mol Mar Biol Biotech 3:294-299

Frelich LE, Blossey B, Cameron EK et al (2019) Side-swiped: ecological cascades emanating from earthworm invasions. Front Ecol Environ 17:502-510. https://doi.org/10.1002/ fee. 2099

Grass I, Kubitza C, Krishna VV et al (2020) Trade-offs between multifunctionality and profit in tropical smallholder landscapes. Nat Commun 11:1186. https://doi.org/10.1038/ s41467-020-15013-5

Hale CM, Frelich LE, Reich PB (2006) Changes in hardwood forest understory plant communities in response to European earthworm invasions. Ecology 87:1637-1649. https:// doi.org/10.1890/0012-9658(2006)87[1637:CIHFUP]2.0. $\mathrm{CO} ; 2$

Hansen MC, Potapov PV, Moore R et al (2013) High-resolution global maps of 21 st-century forest cover change. Science 342:850-853. https://doi.org/10.1126/science.1244693

Hendrix PF, Callaham MA, Drake JM et al (2008) Pandora's box contained bait: the global problem of introduced earthworms. Annu Rev EcolEvolSyst 39:593-613. https:// doi.org/10.1146/annurev.ecolsys.39.110707.173426

IPBES (2019) Summary for policymakers of the global assessment report on biodiversity and ecosystem services of the Intergovernmental Science-Policy Platform on Biodiversity and Ecosystem Services. Paris

James SW, Bartz MLC, Stanton DWG et al (2019) A neotype for Pontoscolexcorethrurus (Müller 1857) (Clitellata). Zootaxa 4545:124

Klarner B, Winkelmann H, Krashevska V et al (2017) Trophic niches, diversity and community composition of invertebrate top predators (Chilopoda) as affected by conversion of tropical lowland rainforest in Sumatra (Indonesia). PloS one 12:e0180915. https://doi.org/10.1371/journal.pone. 0180915

Klein A, Eisenhauer N, Schaefer I (2019) Invasive lumbricid earthworms in North America-different life histories but common dispersal? J Biogeogr 12:674-685

Krashevska V, Klarner B, Widyastuti R et al (2015) Impact of tropical lowland rainforest conversion into rubber and oil palm plantations on soil microbial communities. BiolFertil Soils 51:697. https://doi.org/10.1007/s00374-015-1021-4

Lafont A, Risède J-M, Loranger-Merciris G et al (2007) Effects of the earthworm Pontoscolex corethrurus on banana plants infected or not with the plant-parasitic nematode Radopholus similis. Pedobiologia 51:311-318. https://doi. org/10.1016/j.pedobi.2007.05.004

Lapied E, Lavelle P (2003) The peregrine earthworm Pontoscolex corethrurus in the East coast of Costa Rica: the 7th international symposium on earthworm ecology.Cardiff Wales 2002. Pedobiologia 47:471-474

Larsson A (2014) AliView: a fast and lightweight alignment viewer and editor for large datasets. Bioinformatics 30:3276-3278. https://doi.org/10.1093/bioinformatics/ btu531

Laurance WF, Sayer J, Cassman KG (2014) Agricultural expansion and its impacts on tropical nature. Trends EcolEvol 29:107-116. https://doi.org/10.1016/j.tree.2013.12. 001

Lavelle P, Martin A (1992) Small-scale and large-scale effects of endogeic earthworms on soil organic matter dynamics in soils of the humid tropics. Soil BiolBiochem 24:1491-1498. https://doi.org/10.1016/00380717(92)90138-N

Lopez-Hernandez D, Lavelle P, Fardeau JC, Niño M (1993) Phosphorus transformations in two P-sorption contrasting tropical soils during transit through Pontoscolex corethrurus (Glossoscolecidae: Oligochaeta). Soil BiolBiochem 25:789-792. https://doi.org/10.1016/00380717(93)90124-T

Lubbers IM, van Groenigen KJ, Fonte SJ et al (2013) Greenhouse-gas emissions from soils increased by earthworms. Nat Clim Change 3:187-194. https://doi.org/10.1038/ nclimate 1692

Margono BA, Turubanova S, Zhuravleva I et al (2012) Mapping and monitoring deforestation and forest degradation in Sumatra (Indonesia) using Landsat time series data sets from 1990 to 2010. Environ Res Lett 7:034010. https://doi. org/10.1088/1748-9326/7/3/034010

Margono BA, Potapov PV, Turubanova S et al (2014) Primary forest cover loss in Indonesia over 2000-2012. Nat Clim Change 4:730-735. https://doi.org/10.1038/nclimate2277

Marichal R, Martinez AF, Praxedes C et al (2010) Invasion of Pontoscolex corethrurus (Glossoscolecidae, Oligochaeta) in landscapes of the Amazonian deforestation arc. Appl Soil Ecol 46:443-449. https://doi.org/10.1016/j.apsoil. 2010.09.001

Potapov AM, Klarner B, Sandmann D et al (2019) Linking size spectrum, energy flux and trophic multifunctionality in soil food webs of tropical land-use systems. J AnimEcol 88:1845-1859. https://doi.org/10.1111/1365-2656.13027

Potapov AM, Dupérré N, Jochum M et al (2020) Functional losses in ground spider communities due to habitat-structure degradation under tropical land-use change. Ecology 101:e02957. https://doi.org/10.1002/ecy.2957

Prabowo WE, Darras K, Clough Y et al (2016) Bird responses to lowland rainforest conversion in Sumatran smallholder landscapes Indonesia. PLOS ONE 11:e0154876. https:// doi.org/10.1371/journal.pone.0154876

R Core Team (2019) R: a language and environment for statistical computing. R foundation for statistical computing, Vienna

Rembold K, Mangopo H, Tjitrosoedirdjo SS, Kreft H (2017) Plant diversity, forest dependency, and alien plant invasions in tropical agricultural landscapes. Biol Cons 
213:234-242. https://doi.org/10.1016/j.biocon.2017.07. 020

Righi G (1984) Pontoscolex (Oligochaeta, Glossoscolecidae), a new evaluation. Stud Neotrop Fauna Environ 19:159-177. https://doi.org/10.1080/01650528409360653

Sabrina DT, Hanafi MM, Azwady AAN, Mahmud TMM (2009) Earthworm populations and cast properties in the soils of oil palm plantations. Malays J Soil Sci 13:29-42

Scheu S (2003) Effects of earthworms on plant growth: patterns and perspectives: the 7th international symposium on earthworm ecology · Cardiff · Wales · 2002. Pedobiologia 47:846-856. https://doi.org/10.1078/0031-4056-00270

Schwarzmüller F, Eisenhauer N, Brose U (2015) 'Trophic whales' as biotic buffers: weak interactions stabilize ecosystems against nutrient enrichment. J AnimEcol 84:680-691. https://doi.org/10.1111/1365-2656.12324

Semenina EE, Anichkin AE, Shilenkova OL et al (2015) Rapid extraction of invertebrates from tropical forest litter using modified Winkler apparatus. J Trop Ecol 31:191-194

Shilenkova OL, Tiunov AV (2015) Assimilation of labile carbon and particulate organic matter by tropical endogeic earthworms Pontoscolex corethrurus (Glossoscolecidae, Oligochaeta). Biol Bull 42:696-701

Simberloff D (2011) How common are invasion-induced ecosystem impacts? Biol Invasions 13:1255-1268. https:// doi.org/10.1007/s10530-011-9956-3

Spain AV, Saffigna PG, Wood AW (1990) Tissue carbon sources for Pontoscolex corethrurus (Oligochaeta: Glossoscolecidae) in a sugarcane ecosystem. Soil BiolBiochem
22:703-706. 0717(90)90018-U

https://doi.org/10.1016/0038-

Taheri S, James S, Roy V et al (2018a) Complex taxonomy of the 'brush tail' peregrine earthworm Pontoscolex corethrurus. MolPhylogenetEvol 124:60-70. https://doi. org/10.1016/j.ympev.2018.02.021

Taheri S, Pelosi C, Dupont L (2018b) Harmful or useful? A case study of the exotic peregrine earthworm morphospeciesPontoscolex corethrurus. Soil BiolBiochem 116:277-289. https://doi.org/10.1016/j.soilbio.2017.10. 030

Valéry L, Fritz H, Lefeuvre J-C, Simberloff D (2008) In search of a real definition of the biological invasion phenomenon itself. Biol Invasions 10:1345-1351. https://doi.org/10. 1007/s10530-007-9209-7

Vijay V, Pimm SL, Jenkins CN, Smith SJ (2016) The impacts of oil palm on recent deforestation and biodiversity loss. PLoS ONE 11:e0159668. https://doi.org/10.1371/journal. pone. 0159668

Villesen P (2007) FaBox: an online toolbox for fasta sequences. MolEcol Notes 7:965-968. https://doi.org/10.1111/j.14718286.2007.01821.x

Wurst S (2010) Effects of earthworms on above-and belowground herbivores. Appl Soil Ecol 45:123-130

Publisher's Note Springer Nature remains neutral with regard to jurisdictional claims in published maps and institutional affiliations. 